\title{
Attributes Product That Customers Consider: A Case Of Saving Products In Islamic Rural Bank
}

\author{
Restu Frida Utami ${ }^{1}$, Alfalisyado ${ }^{2}$, Dwi Vina Rahmawati ${ }^{3}$ \\ \{restufridautami06@yahoo.co.id ${ }^{12,3}$ \} \\ Universitas Muhammadiyah Purwokerto, Indonesia
}

\begin{abstract}
The purpose of this study is to determine the attributes considered by customers when saving at a Islamic Rural Bank (BPRS). The attributes analyzed were 8 (eight). The analytical tool used is the analysis of the Fishbein Multi-attribute importance. The population in this study are customers who use the BPRS KU savings product. The sample method used is purposive sampling with the criteria of customers who work as traders. The number of samples was 107 respondents. The results of the study found that the product attributes that customers consider when saving, from the most important to those considered less important, are: security assurance (first order), confidentiality assurance (second order), product quality (third order), service bank (fourth order), sharia principles (fifth order), profit sharing (sixth), bank location and physicality (seventh), bank image (eighth).
\end{abstract}

Keywords: Attribute Product, Multiattribute Fishbein and Islamic Rural Banking

\section{Introduction}

Islamic Rural Bank or Bank Pembiayaan Rakyat Syariah (BPRS) is an intermediary institution that aims to support the implementation of national development to improve equity and economic growth, as well as national stability, towards improving the welfare of many people [1].

BPRS has an important role in the national economy. But unfortunately, this big task is not supported by good performance. BPRS issues that are quite serious include capital limitations, management, IT systems, governance, and government policies. One of the problems of BPRS is capital limitations. That was caused by the lack of ability of the BPRS to get cheap funds from third parties in the form of savings. BPRS that have core capital (MI) under 6 billion reach $68 \%$ of the total 1.797 BPRS. Most of the Third Party Funds came from deposits $(56.97 \%)$ and savings reached $24.18 \%$. The Financial Services Authority (OJK) is an institution that has the authority to regulate and supervise banking institutions providing recommendations to the BPRS to overcome these problems. One recommendation is that BPRS can improve positioning and branding in the community[2].

Positioning is looking for the right position in the market after determining the segmentation strategy used. Positioning can be interpreted as a step of the company to place the product in the minds of consumers where the company has superior features compared to competitors[3]. According to Swasta and Irawan [4], positioning is a marketing strategy by utilizing information to create an impression on the product by the intended market. To succeed in positioning, BPRS are required to be able to offer services that have high value to their customers. So that the value of these services is not only able to meet customer needs but 
can be a differentiating factor with other financial institutions. The way that can be done to run a positioning strategy is by-product attributes [5].

A product, including banking services, is basically a collection of attributes. According to Lovelock and Wright [6] attributes are all features (tangible and intangible) of a good or service that customers can assess. Product attributes become a separate assessment for consumers and can be a distinguishing feature from other products besides that they can help provide consideration before making a product purchase. BPRS can position itself with specific product attributes or features possessed by the product or institution. Selection of appropriate attributes in banking products will be a powerful tool in evaluating brand positioning [7]. Islamic banks must be able to read opportunities and identify what factors are needed [8].

[9] examines the attributes that customers consider in choosing a bank, the case with conventional banks. Research by [10] is a factor that determines customer preferences in the case of deposit products in Islamic banks. [11] examined community preferences for attributes in Islamic banks in Indonesia. Meanwhile, [12] examined the product attributes considered by students for Islamic banking services. Reviewing from previous research, the objects used are commercial banks using both conventional and sharia principles. There has been no research on the object of the BPRS.

This study will discuss the attributes considered by customers in savings products at Islamic Rural Banks. This research is a development from previous research in terms of research objects. The reasons for choosing BPRS as an object of research, as explained above, are that BPRS has an important role in the country's economy, especially the economic development of small communities. Islamic Microfinance Institutions (BMT, Sharia Cooperatives and BPRS) are financial institutions that have smaller coverage, one of which is in the form of capital compared to large-scale bank capital. LKMS has small capital and is intended for the micro and small business sector [13].

Based on these reasons, it is important for BPRS to conduct studies on the behavior of its customers. The perspective of consumer behavior on the attributes of Islamic banks has a close relationship in increasing competitiveness. Therefore, Islamic banks need to identify their customers well, that is, understand their needs and their lifestyle [14] and [15]. Customer perceptions of the value or attributes of banking will influence customers in making decisions to choose conventional or sharia banking [16]. Based on the above background, the following problems are formulated: what are the important attributes that customers consider when saving at a Sharia Rural Bank. The purpose of this study is to determine the important attributes that customers consider when using savings products at BPRS.

\section{Literature Review}

In Islamic banking, product attributes are defined as Islamic nuances of Islamic product attributes offered by Islamic banks [17]. Companies need to be careful in determining product attributes because decisions regarding attributes greatly affect consumer reactions to a product [18]. According to [19] elements of the product are considered important by consumers and are used as the basis for purchasing decisions. 
According to [20] 8 attributes are considered by customers in choosing a bank to save, namely: Types of Services available, Facilities available, Number and inclusion of branch offices, Location, Interest Rate, Community trust, Bureaucracy, Good and friendly service.

[9] examines the attributes that customers consider in choosing a bank, the case with BRI Bank Jambi Branch. The sample criteria are limited to customers aged 18 years using the services of BRI Bank Jambi Branch. After going through the Chocran Q-Test, 8 out of 10 variables were declared valid. Based on the contribution of the attributes considered by the customer in choosing a bank to save, the scores can be sorted:

Tabel l. Attribute Rangking

\begin{tabular}{llc}
\hline \multicolumn{2}{c}{ Attribute } & Score \\
\hline 1. & Types of services provided & 100 \\
2. & Community Trust & 100 \\
3. & Location / Location & 98 \\
4. & Bureaucracy & 98 \\
5. & Gifts or gifts & 98 \\
6. & The number and distribution of branch offices & 97 \\
7. & Interest Rate & 96 \\
8. & Available Facilities & 94 \\
9. & 9. Capital * & 87 \\
10. & Bank Management * \\
\hline \multicolumn{2}{c}{ *not valid } \\
\multicolumn{2}{c}{ Source: [9] }
\end{tabular}

Research by Kontot, Hamali and Abdullah (2015) found that sharia compliance, returns confidence and trust, security, transparency, flexibility of withdrawal schemes were among the determining factors that influence customers' preferences in making decisions. Safety and security, the human touch and zakat are not discussed in this study.

Setiawan, Panduwangi and Sumintono (2018) examined active and inactive customers in Indonesia who use or have used sharia banking services. The results of the Rasch analysis show that the most important attributes considered by customers are security assurance, friendliness, and the Islamic principle. Meanwhile, the attributes that customers do not really consider are social responsiveness, variety and transactions fees.

Table 2. Ranking of Product Attributes

\begin{tabular}{ll}
\multicolumn{2}{c}{ Table 2. Ranking of Product Attributes } \\
\hline \multicolumn{1}{c}{ Attributes To Be Considered } & \multicolumn{1}{c}{ Less Considered Attributes } \\
\hline 1. Assurance & 1. Social Responbility \\
2. Friendliness & 2. Variety \\
3. Islamic Principle & 3. Transactions fees \\
4. Efficiency & 4. Competence \\
5. Comfortable & 5. Systematization \\
6. Cleanliness & 6. Network \\
7. Image & 7. Location \\
8. Environment & 8. Communication \\
9. Flexibility & 9. Profit Sharing \\
\hline \multicolumn{1}{c}{ Source: Setiawan, Panduwangi dan Sumintono (2018) } \\
\hline
\end{tabular}

Source: Setiawan, Panduwangi dan Sumintono (2018)

Rossana and Firmansyah (2019), the results of the Rasch analysis, classify the attributes into two parts, namely 1 ). The most considered attribute, 2). Attributes that are not really considered when choosing an Islamic bank. The results show that the three most important 
attributes of Islamic banking services are considered by customers (students) in the city of Bandung when choosing a sharia bank, namely the attributes of cleanliness, the attributes of hospitality and the attributes of Islamic principles. Meanwhile, the attributes that were not really considered were environment, social responsibility and putting customers first.

Table 3. Ranking of Product Attributes

\begin{tabular}{lll}
\hline \multicolumn{2}{c}{ Attributes To Be Considered } & \multicolumn{2}{c}{ Less Considered Attributes } \\
\hline 1. Cleanliness & 1. & Environment \\
2. Hospitality & 2. Social responsibility \\
3. Islamic Principles & 3. Prioritizing Customers \\
4. Share Results & 4. Network \\
5. Competent & 5. Image \\
6. Systematization & 6. Honesty and morality \\
7. Comfort & 7. Be Careful \\
8. Efficiency & 8. Location \\
& & 9. Security \\
& & 10. Communication \\
\hline
\end{tabular}

Sumber: Rossana dan Firmansyah (2019)

Although previous researchers did not use the exact same attribute variables and analysis methods, previous research had shown inconsistencies with several attributes that were considered the most important or dominant in using banking services.

\section{Method}

The approach used is quantitative descriptive, namely the approach that describes quantitative data on the level of customer interest in the attributes of the BPRS Khasanah Ummat savings product. To analyze the level of customer interest, fishbein multi-attribute analysis is used. Fishbein analysis is also a useful source of information for market planning and action. This model is a consumer evaluation of an object based on its evaluation of the many attributes possessed by these objects, [21]. The use of fishbein multi-attribute analysis aims to determine the most important attributes for customers in using savings products. Respondents will sort the attributes based on their importance, from the most important to rank 1 and those considered less important at rank 8. Then the respondent's answer is given a score for each ranking. The score for each rank is as follows:

\section{Rank 1, Score 8 \\ Rank 2, Score 7 \\ Rank 3, Score 6 \\ Rank 4, Score 5 \\ Rank 5, Score 4 \\ Rank 6, Score 3 \\ Rank 7, Score 2 \\ Rank 8, Score 1}

The population used is the customer of the BPRS Khasanah Ummat savings product. The sample method used is purposive sampling while the criteria are customers who work as traders. The use of traders as research samples, because it adjusts to the target market strategy of BPRS Khasanah Ummat. For data collection, this study used a questionnaire distributed to 
107 vegetable traders in markets, rice stalls, credit sellers, grocery sellers, small shops and others who are classified as small traders. Apart from primary data obtained from questionnaires and interviews. This study uses secondary data obtained from articles / journals, books and publications from the Financial Services Authority (OJK) and BPRS Khasanah Ummat.

\section{Result And Discussion}

Descriptions of the characteristics of respondents in this study are presented in full in the following table:

Table 4. Characteristic Of Respondent

\begin{tabular}{|c|c|c|c|}
\hline Karakteristik & Keterangan & Frekuensi & Persentase \\
\hline \multirow{4}{*}{ Saving Time } & $<1$ Year & 6 & 5,60 \\
\hline & 1 s.d 3 Year & 30 & 28,03 \\
\hline & $>3$ Year & 71 & 66,37 \\
\hline & Total & 107 & 100 \\
\hline \multirow{5}{*}{ Kind of Products } & Tabungan KU & 21 & 19,62 \\
\hline & Tabungan Kurban KU & 4 & 3,74 \\
\hline & Tabungan Ceria KU & 0 & 0 \\
\hline & Tabungan Saku & 82 & 76,64 \\
\hline & Total & 107 & 100 \\
\hline \multirow{6}{*}{ Age } & 17 - 25 Year & 1 & 0,93 \\
\hline & $26-35$ Year & 17 & 15,88 \\
\hline & $36-45$ Year & 24 & 22,42 \\
\hline & $46-55$ Year & 41 & 38,32 \\
\hline & $>55$ Year & 24 & 22,42 \\
\hline & Total & 107 & 100 \\
\hline \multirow{3}{*}{ Religion } & Islam & 107 & 100 \\
\hline & Kristen & 0 & 0 \\
\hline & Total & 107 & 100 \\
\hline \multirow{3}{*}{ Gender } & Female & 71 & 64,6 \\
\hline & Male & 36 & 35,4 \\
\hline & Total & 107 & 100 \\
\hline \multirow{4}{*}{ Education } & SD & 35 & 32,7 \\
\hline & SMP & 36 & 32,7 \\
\hline & SMA & 29 & 26,5 \\
\hline & Sarjana & 7 & 6,2 \\
\hline
\end{tabular}




\begin{tabular}{cccc}
\hline & $\begin{array}{c}\text { Pascasarjana } \\
\text { Total }\end{array}$ & 0 & 1,8 \\
$<$ Rp. 1.000.000,- & $\mathbf{1 0 7}$ & $\mathbf{1 0 0}$ \\
& Rp. 1.000.001 - Rp. 2.000.000,- & 34 & 8,41 \\
Salary per month & Rp. 2.000.001 - Rp. 3.000.000,- & 43 & 40,18 \\
& Rp. 3.000.001 - Rp. 5.000.000,- & 19 & 17,76 \\
& $>$ Rp. 5.000.000,- & 2 & 1,87 \\
& Total & $\mathbf{1 0 7}$ & $\mathbf{1 0 0}$ \\
\hline
\end{tabular}

Based on Table. 1 Characteristics of Respondents, based on how long the respondent's savings were dominated by customers who had saved more than 3 years, 71 people $(66.37 \%)$. Based on simple interviews with the bank, almost every day BPRS employees visit small traders to withdraw savings from traders, this is a ball pick up strategy carried out by BPRS Khasanah Umat to get third party funds from savings products. Judging from the length of time customers save and the many frequencies of saving, it is suspected that the customer is categorized as a customer who has loyalty to the BPRS KU. Being a customer within more than 3 years and making savings transactions repeatedly can be said as a repeat purchase. [4] states that repurchase is an attitude of consumer behavior that only buys a product or service repeatedly without including the favorite aspects in it, to create consumer loyalty which is a commitment to a particular brand or product, store, supplier or company based on a positive attitude reflected in consistent repurchases.

Respondent characteristics based on the type of savings. A savings product that is widely chosen by customers is Tabungan Saku. A total of 82 respondents use Tabungan Saku. Tabungan Saku is one of the savings products from BPRS Khasanah Ummat, the reasons why this product is in great demand by customers include the cost of opening an account, minimum deposit and the minimum deposit to settle relatively small or cheap, making it affordable by small traders.

Judging from the age characteristics, customers who save at BPRS Khasanah Ummat have a varied age distribution, this shows that each stage of age has interests and goals for saving. Based on the religious characteristics of the respondents, all respondents (100\%) are Muslim, this condition is allegedly due to the image of the Islamic BPRS Khasanah Ummat based on Islamic principles so that many Muslims choose the BPRS Khasanah Ummat as a place to save. Based on gender characteristics, BPRS Khasanah Umat customers in the morning market are dominated by women. The education level of respondents, spread fairly evenly starting from the elementary level (37\%), junior high $(37 \%)$, high school $(30 \%)$, it can be concluded that BPRS Khasanah Ummat is the choice of customers in various levels of education. Based on the level of income, respondents who work as small traders have income levels that vary from 1 million to 5 million, but few of the small traders have an income of less than 1 million and are rare for respondents who have income above 5 million.

Table 5. Attribute Value and Priority Order of Interest Customer Attributes

\begin{tabular}{ccc}
\hline Attribute & $\begin{array}{c}\text { Attribute } \\
\text { Value }\end{array}$ & $\begin{array}{c}\text { Priority Order of Interest } \\
\text { Customer Attributes }\end{array}$ \\
\hline Security Guarantee & 777 & 1 \\
\hline
\end{tabular}




\begin{tabular}{cll}
\hline Confidentiality guarantee & 674 & 2 \\
Product quality & 551 & 3 \\
Bank Services & 508 & 4 \\
Sharia Principles & 446 & 5 \\
Profit-Sharing & 356 & 6 \\
Location and Physical Bank. & 297 & 7 \\
Image Bank & 214 & 8 \\
\hline
\end{tabular}

Source: Processed Data

In the table. 2 shows the priority of importance for the most considered attributes until the attributes that are less considered by BPRS Khasanah Ummat customers in using savings products, namely: Security Guarantee (first order) with an attribute value of 777 points, Confidentiality Guarantee (second place) with an attribute value of 674, Product Quality (third order) with an attribute value of 551, Bank Services (fourth) with an attribute value of 508, Sharia Principles (fifth) with an attribute value of 446, Profit Sharing (sixth) with an attribute value of 356, Location and Physical Bank (seventh) with an attribute value of 297 and Citra Bank (eighth) with an attribute value of 214.

107 BPRS customers who work as traders prioritize guaranteeing the safety of funds when they use savings products. This research is in line with the research of [22] and [11], in their research, they also found that the attribute of security assurance is the most considered attribute in using Islamic banking products. However, this study is not in line with the research of [9] and [23]. [9] uses 8 attributes and finds that customers in conventional banks consider the attributes more: services, facilities, number and distribution of offices, bank location and interest rates. Only then do customers consider their trust in the bank. [23] found that customer trust and bank credibility and social responsibility are the fourth group of factors that customers consider in using Islamic banking services.

The attribute that is considered by the customer, in the second place is the guarantee of confidentiality. This research is supported by research by [9], found that the flexibility factor, which includes the confidentiality variable, is more considered by customers in choosing deposit products than the bank competency factor. [2], assessing the credibility or professionalism of a bank is based on three factors: 1) professional accuracy and prudence, 2) confidentiality, 3) impartiality. What is meant by confidentiality is that bankers must be able to store financial information regarding a project or cooperation, the bank may not exploit or disclose information without written permission. This also relates to the principles of the bank, namely morality and honesty.

The third attribute that customers consider is product quality. Product quality is a combination of various types of products, the ability of the product to meet needs. This study is in line with [23] that the availability of services or product diversity is the third factor that customers in Malaysia consider. Fulfilling the dimensions of service product functions will encourage potential customer interest in Islamic Bank, [27]. However, the results of this study are contrary to [11], the results show that diversity is a factor that customers do not really consider when saving.

The attribute that the customer then considers is service quality (fourth). The results of this study are supported by research by [23], where the combination of the quality and convenience of a bank is the main factor that customers consider when choosing an Islamic bank. Service 
quality is a factor that determines the level of success and quality of the company where the company's ability to provide quality service to consumers Zeithmal, et al (1996) in [27].

The 5th order attribute considered by the customer is BPRS operations based on sharia principles. Although BPRS Khasanah Ummat is a bank based on principles, customers do not include these attributes as the main consideration when saving. Customers prefer the combination of the guarantee attributes provided by the bank, the quality of the bank's products and services. This research is in line with [23]. However, this study contradicts the study conducted by [22] and [10]. [22] in their research related to profit loss sharing (profit sharing) shows that a customer chooses the attributes of a sharia bank because of religious motives, namely Islamic principles, in the profit sharing system and guarantees of customer safety when making financial transactions. [10] found that sharia compliance is more considered in the decision to use sharia banking services.

The basic principles in the Islamic financial system are the unique product attributes of Islamic banking [28]. If the benefits of these distinctive attributes can be felt by the customer, the customer will give a positive assessment of the attributes of the Islamic product, [29]. The big task for BPRS is how to implement sharia principles which are reflected in the attributes of banking products so that customers will experience the benefits and differences of Islamic bank products compared to conventional bank products.

The profit sharing attribute ranks sixth, meaning that this attribute is not considered by customers when saving. This research is in line with research conducted by [9] and [11] that the interest rate and profit sharing are not considered by customers. This study is different from [23] and [22]. [23] availability of prices which includes a combination of transaction costs, deposit benefits, product prices, availability of credit, including important factors that are prioritized by customers. Although this attribute is not considered by customers, BPRS must still pay attention to this because the share of profits for banks and the share of profits for customers in Islamic banks is quite sensitive, so it needs clarity. Clarity in the profit section will influence customers to use banking product services.

The attributes that are not considered by customers when using savings products are the location and appearance of the bank (seventh). This may happen because when customers are saving, they don't need to come to the office, there is a deposit and withdrawal pick-up service for customers so that customers don't really consider the location and appearance attributes of the bank. This research is in line with the research of [12]. However, the results of this study do not support the results of [9] study which found that the location of the bank ranks 3rd out of 10 attributes. This shows that the attribute location / location of the bank is an important factor to consider when using banking services.

The most recently considered attribute of the eight existing attributes is the image of the bank. This study is in line with [8] research which examined 3 variables, namely: service and trust variables, characteristic variables and knowledge variables. Knowledge variables include the banking system, Islamic bank information and bank image. However, this research is not in line with [22), customers will be willing to transact with Islamic banks with a good image and reputation. Customers see the image and reputation of the bank through advertisements, bank size and network size, and third party recommendations, image and reputation are the second important factors. Nevertheless, BPRS are required to make efforts to improve and maintain the image and reputation of the bank because images such as popularity, reputation, credibility and professionalism of Islamic banks will encourage potential customers to consider becoming customers at the Islamic bank, [27].

Each product has different attributes so that consumers are faced with various attributes offered by the company, [30]. Product attributes are everything that is attached to the product 
and gives identity to the product and is considered important by consumers and is used as the basis for purchasing decisions, [3]. The strategy of presenting the service product attributes offered by sharia bank management that is adjusted to the level of customer needs and desires is the right choice to attract customer saving interests, [27]. Product attributes are a way for BPRS to attract customers. Therefore, BPRS are required to offer product attributes that can fulfill customer wants and needs.

\section{Conclusions}

Based on the results of data analysis and discussion, it is concluded, the attributes of savings products that are considered most important to the attributes that are considered less important for customers when saving in sequence, namely: Security guarantees (first-order), Secrecy guarantees (second-order), Product quality (third-order), Bank services (fourth-order), Islamic principles (fifth-order), profit sharing (sixth-order), location and physical bank (seventh order), bank image (eighth order).

For further research, it is better to add other attributes to be analyzed. BPRS needs to pay attention to product attributes that are considered by customers when saving as a basis for determining bank strategy so that BPRS performance will be more effective and efficient. Research needs to be done about customer attitudes towards product attributes so that BPRS will know how customers' attitudes towards product attributes.

\section{References}

[1] Undang-Undang Republik Indonesia No. 21 Tahun 2008 Tentang Perbankan Syariah.

[2] Otoritas Jasa Keuangan. 2016. Tantangan Dan Permasalahan BPRS. Rakernas Dan Seminar Nasional: Pontianak

[3] Kotler, Philip., Kevin L. Keller. 2006. Manajemen Pemasaran edisi ke 12 Jilid ke 1. New Jersey, IndeksSwasta, Basu., Dharmesta dan Irawan. 2008. Manajemen Pemasaran Modern. Liberty: Yogyakarta.

[4] Kotler, Philip. 2006. Manajemen Pemasaran, Edisi Pertama. PT. Indeks Kelompok Gramedia: Jakarta.

[5] Lovelock, Christoper., Wright, Lourent. 2005. Manajemen Pemasaran Jasa. PT. Indeks: Jakarta.

[6] Gwin, C. F., \& Gwin, C. L. 2015. Product Attributes Model: a Tool For Evaluating Brand Positioning. 11, 30-42.

[7] Maski, Ghozali. 2010. Analisis Keputusan Nasabah Menabung: Pendekatan Komponen Dan Model Logistik Studi Pada Bank Syariah Di Malang. Journal of Indonesian Apllied Economics. Vol 4, No. 1: 43-57.

[8] Azizah. 2011. Atribut Yang Menjadi Pertimbangan Nasabah Dalam Memilih Bank (Studi Kasus Pt Bank Rakyat Indonesia Cabang Jambi). Jurnal Ilmiah Universitas Batanghari Jambi Vol.11 No.1: 17-24

[9] Kontot, Keria., Jamil Hamali dan Firdaus Abdullah. 2016. Determining Factors of Customers' Preferences: A Case of Deposit Products in Islamic Banking. Procedia - Social and Behavioral Sciences $224 \quad 167-175$

[10] Setiawan, B., Panduwangi, M., \& Sumintono, B. (2018). A Rasch Analysis Of The Community's Preference For Different Attributes Of Islamic Banks In Indonesia. International Journal of Social Economics, 45 
[11] Rossana, A., \& Firmansyah, E.A. (2019). Analisis Rasch Pada Atribut Perbankan Syariah: Sudi Pada Generasi Milenial. Jurnal Ilmiah Ekonomi Islam, 5(03), 145-. doi:http://dx.doi.org/10.29040/jiei.v5i3.530

[12] Hamdan. 2012. "Baitulmal wattamwil dan BPR", makalah yang disampaikan pada Dilkat III Program PPC Terpadu Angkatan VI Peradilan Agama Seluruh Indonesia. Pusdiklat Balitbang Diklat Kumdil MA-RI Megamendung: Bogor

[13] Moon, S. Y., Philip, G. C., \& Moon, S. 2011. The Effects Of Involvement On e-Satisfaction Models. Services Marketing Quarterly, Vol. 32 (4), 332-342.

[14] Khan, F. 2010. How "Islamic" is Islamic banking? Journal of Economic Behavior and Organization, Vol. 76 (3), 805-820.

[15] Wulandari, D., \& Subagio, A. 2015. Consumer Decision Making in Conventional Banks and Islamic Bank based on Quality of Service Perception. 211, 471-474.

[16] Junusi, EL, Rahman, 2009. Pengaruh Atribut Produk Islami, Komitmen Agama, Kualitas Jasa dan Kepercayaan terhadap Kepuasan dan Loyalitas Nasabah Bank syariah pada Bank Muamalat Kota Semarang). Annual Conference On Islamic Studies (ACIS). Jurnal Manajemen.

[17] Kotler, Philip., George, Amstrong, 2008. Prinsip-Prinsip Pemasaran. Edisi 12 Jilid 1. Erlangga: Jakarta.

[18] Tjiptono, Fandy., 2007. Strategi Pemasaran. Edisi Kedua. Andi Ofset:Yogyakarta.

[19] Simamora, Bilson., 2003. Membongkar Kotak hitam Konsumen. PT Gramedia Pustaka: Jakarta.

[20] Engel, James F, Roger D. Blackwell \& Paul W. Minard. (1994). Perilaku Konsumen. Jilid Ke 1 \& 2. Bina Rupa Aksara: Jakarta.

[21] Amin, M., Isa, Z., \& Fontaine, R. (2013). Islamic Banks: Contrasting The Drivers Of Customer Satisfaction On Image, Trust, And Loyalty Of Muslim And Non-Muslim Customers In Malaysia. International Journal of Bank Marketing,3(1).

[22] Echchabi, A., \& Nafiu Olaniyi, O. (2012). Malaysian Consumers' Preferences For Islamic Banking Attributes. ", International Journal Of Social Economics, 39.

[23] Suhardi, Gunarto. (2008). Pengaruh Atribut Yang Dipertimbangkan Dalam Pemilihan Produk Deposito Perbankan Terhadap Kepercayaan Dan Dampaknya Pada Loyalitas Nasabah. Kinerja. 12 (1): 100-109.

[24] Bidabad, B., \& Sherafati, M. (2016). Operational Ethical Banking in Rastin Banking (Professional Ethics, Auditing, Inspection, Control, Monitoring, and Preservation). International Journal of Law and Management, 5 (8).

[25] Roni, Andespa., (2018). Analisis Sikap Nasabah Terhadap perbankan Syariah Di Sumatera Barat. Maqdis: Jurnal Kajian Ekonomi Islam, 3 (1), 113-122

[26] Lupiyoadi, Rambat dan Hamdani, A. (2008). Manajemen Pemasaran Jasa. Cetakan Keempat. Edisi Dua. Jakarta: Salemba Empat

[27] Iqbal, Z. (1997). Islamic financial systems. Finance \& Development. Vol. 34 No. 2, 42-5

[28] Sitinjak, Rutmaira (2015). Analisis Pengaruh Atribut Produk Islami Dan Kualitas Pelayanan Terrhadap Kepuasan Nasabah Dan Loyalitas Nasabah Pada Pt Bank Negara Indonesia Syariah (Bni Syariah) Pekanbaru. Jom Fekon Vol. 2 No. 2

[29] Ali, Karnila. (2017). Pengaruh Promosi Dan Atribut Produk Terhadap Keputusan Nasabah Dalam Memilih Tabungan Ekasave Pada Bank Eka Kantor Pusat Metro

[30] Arikunto, S. 2002. Metodelogi Penelitian. Rieneka Cipta: Jakarta 